\title{
Grazing management effects on plant species diversity in tallgrass prairie
}

\author{
KAREN R. HICKMAN, DAVID C. HARTNETT, ROBERT C. COCHRAN, AND CLENTON E. OWENSBY
}

Authors are Associate Professor, Department of Biological Sciences, 600 Park Street, Ft. Hays State University, Hays, Kans. 67601; Professor, Division of Biology; Professor, Department of Animal Science and Industry; Professor, Department of Agronomy, Kansas State University, Manhattan, Kans. 66506. Corresponding author is Karen R. Hickman.

Abstract

A 6-year study was conducted in tallgrass prairie to assess the effects of grazing management (cattle stocking densities and grazing systems) on plant community composition and diversity. Treatments included sites grazed season-long (May to October) at 3 stocking densities $(3.8,2.8$, and 1.8 hectares per animal unit), ungrazed control sites, and sites under a late-season rest rotation grazing system at this same range of stocking densities. Plant communities were sampled twice each season using a nearestpoint procedure. Native plant species diversity, species richness, and growth form diversity were significantly higher in grazed compared to ungrazed prairie, and diversity was greatest at the highest stocking density. This enhancement of plant species diversity under grazing was not a result of increased frequency of weedy/exotic species. There were no significant effects of grazing system on plant diversity, nor any significant stocking density $\mathbf{x}$ grazing system interactions, indicating that animal density is a key management variable influencing plant species diversity and composition in tallgrass prairie and that effects of animal density override effects of grazing systems. Increasing cattle stocking densities decreased the abundance of the dominant perennial tall grasses, and increased abundance of the $C_{4}$ perennial mid-grasses. The frequency of perennial forbs was relatively stable across grazing treatments. Abundance of annual forbs varied among years and grazing treatments. In half of the years sampled, annual forbs showed the highest frequency under intermediate stocking density. Patterns of responses among plant groups suggest that some species may respond principally to direct effects of grazers and others may respond to indirect effects of grazers on competitive relationships or on the spatial patterns of fuel loads and fires. Thus, this study suggests that large grazer densities, fire, and annual climatic variability interact to influence patterns of plant community composition and diversity in tallgrass prairie. Effects of varying management such as stocking densities and grazing systems on plant species diversity and the relative abundances of different plant growth forms or functional groups may have important consequences for grassland community stability and ecosystem function.

Key Words: biodiversity, plant ecology, cattle grazing, Flint Hills, range management, grazing systems, stocking rates

This research was supported by USDA grant No. 9502643 to D.C. Hartnett and R.C. Cochran. This paper is contribution No. 03-311-J from the Kansas Agricultural Experiment Station, Manhattan, Kans. We appreciate discussions and numerous constructive comments by A.K. Knapp, J.M. Blair, D.M. Engle, E.E. Towne, and two anonymous reviewers. Valuable statistical advice and assistance were provided by R. Channell and K. Rice.

Manuscript accepted 14 Mar. 03.

\section{Resumen}

Se condujo un estudio de ó años en una pradera de zacates altos para evaluar los efectos del manejo del apacentamiento (densidades de carga animal y sistems de apacentamiento) en la diversidad y composición de la comunidad vegetal. Los tratamientos incluyeron sitios apacentados estacionalmente (Mayo a Octubre) con 3 densidades de carga (3.8, 2.8 y 1.8 hectáreas por unidad animal), sitios control sin apacentamimento y sitios con apacentamiento rotacional con descanso a fines de la estacion de crecimiento con las mismas densidades de carga animal. Las comunidades vegetales se muestrearon dos veces en cada estación usando el procedimiento del punto más cercano. La diversidad de especies de plantas nativas, la riqueza de especies y la diversidad de formas de crecimiento fueron significativamente mayores en las praderas apacentadas que en las no apacentadas, y la diversidad más alta se dio con la mayor carga animal. Este incremento de la diversidad de especies vegetales bajo apacentamiento no fue resultado de un aumento de la frecuencia de especies tóxicas/ maleza. No hubo efectos significativos del sistema de apacentamiento en la diversidad de especies, ni ninguna interacción significativa entre densidad de carga aninal x sistema de apacentamiento, indicando que el densidad animal es una variable de manejo clave que influencia la diversidad y composicion de especies de las paraderas de zacates altos y que los efectos de la densidad animal anulan los efectos de los sistemas de apacentamiento. Al aumentar la densidad de carga disminuye la abundancia de zacates altos perennes dominantes e incrementa la abundancia de zacates medianos prennes $\mathrm{C}_{4}$. La frecuencia de hierbas perennes fue relativamente estable a través de los tratamientos de apacentamiento. La abundancia de hierbas anuales varió entre años y tratamientos de apacentamieto. En la mitad de los años muestreados las hierbas anuales mostraron la mayor frecuencia bajo las densidades de carga intermedias. Los patrones de respuesta entre los grupos de plantas sugieren que algunas especies pueden responder principalmente a los efectos directos de los herbívoros y otras pueden responder a efectos indirectos de los herbívoros en relaciones competitivas o en los patrones espaciales de cargas de combustible y fuegos. Así, este estudio sugiere que altas densidades de animales apacentando, el fuego y la variabilidad climática anual interactuan para influenciar los patrones de composición de la comunidad vegetal y la diversidad de las praderas de zacates altos. Efectos de variación del manejo, tales como densidades de carga y sistemas de apacentamiento, en la diversidad de especies y abundancias relativas de diferentes formas de crecimiento vegetal o grupos funcionales pueden tener importantes consecuencias para la estabilidad de las comunidades de pastizal y función del ecosistema. 
Grassland species diversity and other plant community responses to ungulate grazing may be strongly influenced by management practices. Grazing systems are tools which allow range managers to control the frequency and duration of grazing and non-grazing periods to optimize livestock and plant performance and sustain desirable plant community composition (Heitschmidt and Taylor 1993). Some grazing systems were originally developed in an attempt to simulate historical spatial-temporal patterns of grazing by native ungulates (Smith 1895, Coughenour 1991). Vegetation and animal responses to various grazing systems have been studied in several grassland ecosystems (e.g., Owensby et al. 1973, Heitschmidt et al. 1987, Hart et al. 1988, Gillen et al. 1991, 1998). Recently, grazing system research has focused on assessing temporal and spatial livestock distributions that maintain or improve yields of the dominant forage plant species concurrent with maximizing animal production.

Many early studies on grazing systems did not consider the strongly interacting effects of animal stocking density (Gammon 1978). The few studies that did examine these factors together suggest that vegetation responses to grazing systems may be strongly dependent on or over-ridden by effects of stocking density (e.g., Gammon and Roberts 1978, Hart 1978, Heitschmidt et al. 1987). Few grazing system studies have been carried out at a range of stocking densities, nor have they assessed the effects of different grazing system/stocking density interactions on plant species diversity or other aspects of grassland community structure and dynamics. Hence, the long-term ecological consequences of the implementation of various livestock grazing systems remain poorly understood.

Recent assessments of biodiversity in grassland ecosystems (Archer and Smeins 1991, West 1993, Biondini et al. 1998, Stohlgren et al. 1999) indicate its importance in maintenance of the long-term sustainability of rangeland ecosystem processes including soil stability, nutrient cycling, plant-herbivore interactions, and the stability of plant species composition and net primary production (Tilman 1996, Schlapfer and Schmid, 1999). Therefore, changes in plant community structure and diversity which occur as a result of varying grazing systems and intensities are important given their potential effects on these ecosystem processes.

The objective of this study was to assess the effects of variation in the spatial-tem- poral patterns of herbivory associated with different cattle grazing systems and stocking densities on plant species composition, diversity (species richness and evenness) and vegetation structure in tallgrass prairie. Specifically, we examined effects of 2 grazing systems, a late-season rest rotation (hereafter referred to as "rest rotation") and season-long stocking (hereafter referred to as "season-long"), at 3 cattle stocking densities in Kansas tallgrass prairie. Previous research in tallgrass prairie suggested that a late-season rest of pastures grazed early in the growing season promotes replenishment of carbohydrate reserves in the dominant rhizomatous, warm-season perennial grasses [e.g., big bluestem (Andropogon gerardii Vittman) and Indian grass (Sorghastrum nutans (L.) Nash)] (McKendrick et al. 1975, Owensby et al. 1977). In addition, regrowth during the rest period produces adequate fuel for more complete prescribed spring burns (Smith and Owensby 1978), thus promoting increased production and dominance of $\mathrm{C}_{4}$ tall grasses, a decrease in the number of annual forb species and woody invaders and decreased spatial heterogeneity in the plant community (Towne and Owensby 1984). These effects are hypothesized to reduce heterogeneity and plant species diversity in tallgrass prairie. Late-season rest of all pastures is generally not feasible for ranching operations managing year-round cow-calf herds, however the incorporation of a rotational component at the end of the season allows for year-round maintenance of the herd. In addition to these potential effects of grazing systems, increased stocking density is predicted to increase plant species richness, but may decrease community stability through high intensity herbivory, increased soil disturbance, and increased frequency of annual species.

The tallgrass prairie is North America's most endangered ecosystem, occupying only about $4 \%$ of its pre-settlement area (Samson and Knopf 1996). The Flint Hills region covers over 2 million ha and comprises the largest contiguous area of remaining tallgrass prairie in North America. Grazing by large mammals and periodic fire historically have been key natural ecological processes shaping and maintaining these grassland ecosystems, and these 2 processes remain key components of land management throughout this region today. This region also represents an important resource for livestock production. Kansas supports a total of 6 million animal unit months, principally on Flint Hills tallgrass prairie, and the state is second only to Texas in total livestock production on native rangelands. Thus, an understanding of the long-term consequences of these alternative range management practices for the biodiversity and functioning of tallgrass prairie plant communities in this region is of both economic and conservation importance.

\section{Methods}

A 6-year study was initiated in 1992 on the Kansas State University Range Research Unit, a 522 ha site located in the Flint Hills region of Kansas $\left(39^{\circ} 05^{\prime} \mathrm{N}\right.$, $\left.96^{\circ} 35^{\prime} \mathrm{W}\right)$. This native tallgrass prairie site is dominated by a matrix of perennial $\mathrm{C}_{4}$ grasses [big bluestem, Indian grass, little bluestem (Schizachyrium scoparium (Michx.) Nash), and switchgrass (Panicum virgatum L.)] with numerous subdominant grasses, composites, legumes, other forbs, and a few locally common woody species. The study site, previously described by Herbel and Anderson (1959) and Anderson and Fly (1955), has been a site of research on livestock grazing and prescribed burning since the early 1950's (e.g., Anderson, et al. 1970, Owensby et al. 1973, 1995). Average monthly temperature ranges from a minimum of $-2.7^{\circ} \mathrm{C}$ in January to a July high of $26.6^{\circ} \mathrm{C}$. Average annual total precipitation is 835 $\mathrm{mm}$. Total annual precipitation during 1992-1997 was 871, 1228, 637, 989, 783, and $741 \mathrm{~mm}$, respectively. Average annual precipitation during the study period was $875 \mathrm{~mm}$, within $5 \%$ of the long-term average. Average annual aboveground net primary productivity in Flint Hills tallgrass prairie, as measured by the NSF long-term ecological research program at nearby Konza Prairie Biological Station, is $365 \mathrm{~g}$ $\mathrm{m}^{-2}$ year $^{-1}$, ranging from $250 \mathrm{~g} \mathrm{~m}^{-2}$ year $^{-1}$ in dry years to $>600 \mathrm{~g} \mathrm{~m}^{-2}$ year ${ }^{-1}$ in years with above-average precipitation (Briggs and Knapp 1995).

The 13 pastures used in this study (avg size $=29$ ha) were grazed from approximately 13 May to 1 October each year (1992 to 1997) and varied in animal density and grazing system. During the study all pastures were burned annually in lateApril, as this is the typical range management practice throughout the Flint Hills tallgrass prairie. Launchbaugh and Owensby (1978) recommended frequent fire as a part of management for Kansas Flint Hills range. Also, since fire impacts grazing distribution, burning in all years prevents a potential confounding effect. One pasture remained ungrazed (control) 
throughout the study. The 12 other pastures were randomly assigned to grazing system with 9 pastures designated for the late-season rest rotation grazing system and 3 pastures designated for season-long grazing. Each of the 3 pastures assigned to the season-long grazing were randomly assigned to 1 of the 3 stocking densities [low $(\mathrm{L})=3.8$, moderate $(\mathrm{M})=2.8$, and high $(\mathrm{H})=1.8$ ha per cow-calf pair; season-long $\mathrm{L}$, season-long $\mathrm{M}$, and seasonlong H]. Stocking densities were set such that the moderate stocking density treatment was projected to result in a $50 \%$ utilization of annual aboveground net primary production. This chosen density was based on extensive previous studies of cattle and forage utilization in the Flint Hills, and represents the Natural Resources Conservation Service recommended moderate stocking rate/density and the typical grazing intensity for the region. The low and high stocking densities represent a 1 ha per cow-calf pair decrease or increase from the moderate density.

The 9 pastures designated for late-season rest rotation treatments were divided into 3 sets. Each of these sets was randomly assigned to 1 of the 3 stocking densities listed above. All rest-rotation pastures were grazed rotationally from approximately 15 May to 15 July each year. There was no significant year to year variability in total cow-calf biomass put on each pasture, nor were there significant differences in cattle production among the treatments. Within pastures of similar stocking density, each received similar grazing intensities from mid-May to mid-July. Thereafter, 1 of the 3 pastures was rested (ungrazed), and grazing was restricted to the remaining 2 of the 3 pastures within each stocking density treatment, with the cattle from the pasture designated for the late-season rest being evenly distributed among the remaining 2 . These remaining 2 rest-rotation pastures were then grazed until the beginning of October. Thus, while the rested pasture was ungrazed during the latter half of the growing season, the 2 non-rested pastures experienced a late-season grazing intensity that was 50\% higher than the early-season (May 15 to July 15 density). The late-season rest was rotated annually among the 3 pastures at each stocking density, allowing for 2 complete rotations throughout the 6 years of this study.

Within each pasture, the frequency of each plant species was sampled using a nearest-point sampling procedure (Owensby 1973) along four, 100-m transects (100 points/transect). Along each transect 100 randomly located points were selected and the nearest rooted plant to each point was identified to species and recorded. Generation of species accumulation curves indicated that 100 points were sufficient to encounter more than $90 \%$ of the species present. The transects were established in a stratified random fashion by range site, including 2 loamy upland transects (Tully series: fine, mixed, mesic, montmorillonitic, Pachic Argiustolls) and 2 shallow soil transects (Benfield-Florence soil series complex). These represent the 2 major range sites of the study area, comprising approximately $60-70 \%$ of the total area of the pastures. Replicate transects in each pasture were at least $400 \mathrm{~m}$ apart. Hereafter, these transects will be referred to as the "primary transects". Plant communities were sampled twice each season, once in the early growing season (lateMay) and once at the time of peak aboveground biomass (late-August) to adequately sample all species actively growing at various periods. Because we were interested in the effects of these treatments on plant species richness and diversity, we modified the nearest point procedure to obtain more precise estimates of the frequency of the subdominant and rare forb species. We conducted a secondary sampling along each $100-\mathrm{m}$ transect, recording only the nearest forb to each sampling point. The total frequency of all forbs was calculated from the primary sampling and multiplied by the frequency of each forb species obtained from the secondary forbspecies-only sampling to determine the actual frequency of each forb species on each transect. For each plant species, the maximum frequency from the 2 sampling periods within each year was retained for analysis.

Species relative abundances and Shannon species diversity index $\left[\mathrm{H}^{\prime}=-\Sigma\right.$ $p_{\mathrm{i}} \cdot \ln p_{\mathrm{i}}$ ] (Magurran 1988) were determined by calculating the frequency of each plant species $\left(p_{i}=\right.$ proportion of points along each transect at which species i was recorded). Plant species richness $(S=$ number of species sampled per transect) and evenness of species abundances (Pielou's $\mathrm{J}$ index $=\mathrm{H}^{\prime} / \mathrm{lnS}$ ) were also calculated for each transect. Because the lateseason rest-rotation grazing system required 3 pastures for the annual restrotation at each stocking density, for each stocking density we used the means of transects from the 3 pastures. Statistical analysis (MANOVA) of early-season 1992 sampling showed no significant initial differences in species richness $(\mathrm{F}=$ $.809, \mathrm{P}=.639)$ or diversity $(\mathrm{F}=.421, \mathrm{P}=$
.946) among pastures assigned to different grazing systems or between grazed versus ungrazed sites. The random assignment of treatments to pastures, and the lack of any significant differences in initial plant community composition, soil type, topography, etc. between pastures provided a high degree of confidence that patterns observed in subsequent years could be attributed to treatments and were not confounded by initial differences. Logistically, it was impossible to replicate all treatment combinations in these experiments at the pasture level. However, replication and wide spacing (stratified-random) of transects insured that plant community responses measured at 1 transect were completely independent of any effects of plant responses at other transects. Our first step in data analysis was to assess statistical differences in grazed versus ungrazed treatments. Initially, we conducted unpaired t- tests to assess plant community differences between transects of grazed and ungrazed treatments. Species richness and diversity showed significant differences between grazed and ungrazed treatments. Further analyses addressed variation among the different grazing treatments. A repeated measures MANOVA (Wilks' Lambda) was used to assess statistical differences in plant community response variables (e.g. species richness and species diversity) between years, and interactions of years $x$ grazing system, years $x$ stocking density, and years $\mathrm{x}$ grazing system $\mathrm{x}$ stocking density. Data from grazing system treatments which showed no significant differences in the MANOVA results were then pooled within stocking density, following which we conducted a Tukey HSD for determination of plant community response differences between stocking densities.

To assess changes in plant growth form composition, all plant species were classified into 9 growth form categories, including $\mathrm{C}_{4}$ perennial short-, mid-, and tall grasses, $\mathrm{C}_{4}$ annual grasses, $\mathrm{C}_{3}$ perennial grasses, $\mathrm{C}_{3}$ annual grasses, annual forbs, perennial forbs, and woody species. Frequencies of the various growth forms were also used to calculate growth form diversity using Shannon diversity index $\left[\mathrm{H}^{\prime}=-\sum p_{\mathrm{i}} \cdot \ln p_{\mathrm{i}}\right]$, where $p_{\mathrm{i}}=$ the proportional contribution of plants of growth form i to the plant community. Treatment differences in growth form frequency were assessed using a non-parametric repeated measures MANOVA (Wilks' Lambda) followed by a Tukey HSD. 


\section{Results}

After 6 years of the various grazing treatments, several significant patterns emerged between grazed and ungrazed grazing treatments. Grazed pastures showed significantly higher ( $\mathrm{t}$-test; $\mathrm{t}=$ 5.158; $\mathrm{P}<0.001)$ plant species richness $(36.0 \pm 0.33)$ than the ungrazed pasture $(29.9 \pm 0.933)$. After 6 years of grazing, grazed treatments also had significantly higher plant species diversity $(2.5 \pm 0.11)$ than the ungrazed treatment $(2.2 \pm 0.14)$. Subsequent analyses assessed differences in community responses among the various grazed treatments. Repeated measures MANOVA indicated there were no significant differences in plant species richness, diversity, evenness, or growth form diversity between the 2 grazing systems (Table 1). However, cattle stocking density had significant effects $(P \leq 0.05)$ on plant species richness, Shannon diversity index $\left(\mathrm{H}^{\prime}\right)$, and growth form diversity (Table 1 ). Therefore, further comparisons only consider grazing intensity (stocking density) effects.

Plant species richness was significantly higher in the high stocking density treatments than the low and moderate stocking densities (Tukey's; P $<0.001$ ), with no significance between the moderate and low stocking densities (Tukey's; $\mathrm{P}=$ 0.766; Fig. 1). There was some interannual variability in plant species richness in

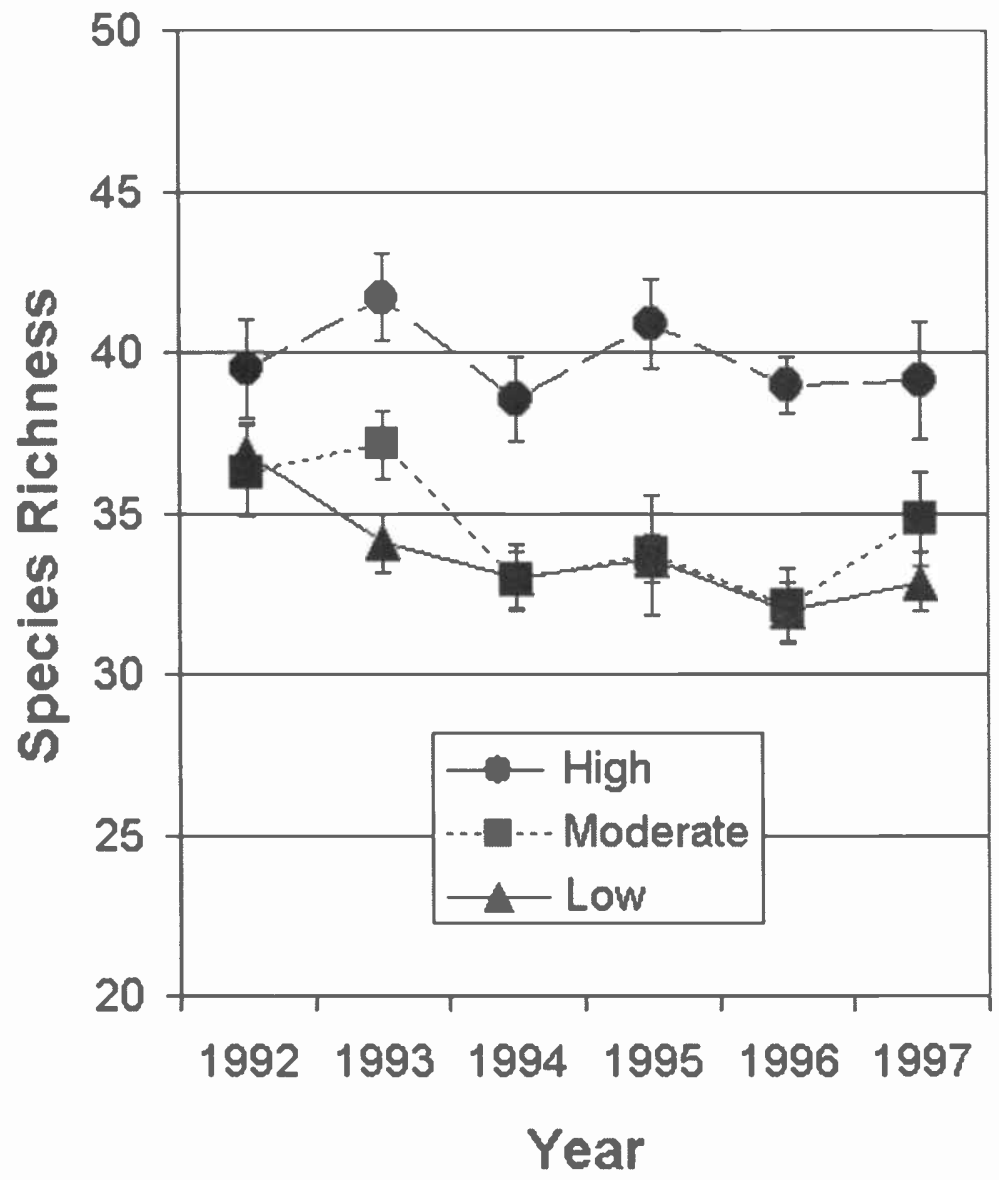

Fig. 1. Annual means $\pm 1 \mathrm{SE}$ (1992-1997) of plant species richness per treatment each year of study at varying stocking densities in Kansas tallgrass prairie. Species richness $=$ number of species/transect. STOCKING DENSITIES: Low $=3.8$ hectares/cow-calf pair, moderate (2.8 ha/cow-calf pair), and high ( $1.8 \mathrm{ha} /$ cow-calf pair).
Table 1. Results of a repeated measures MANOVA (Wilks' lambda).

\begin{tabular}{lccc}
\hline \hline & F Value & p value & Power \\
\hline YEARS & & & \\
Richness & 3.536 & .010 & .874 \\
Diversity & 3.308 & .014 & .848 \\
Evenness & 5.107 & .001 & .889 \\
GF Diversity & 2.129 & .083 & .651
\end{tabular}

YEARS * GRAZING SYSTEM

$\begin{array}{lrrl}\text { Richness } & 2.106 & .086 & .631 \\ \text { Diversity } & 1.461 & .225 & .456 \\ \text { Evenness } & 1.515 & .208 & .424 \\ \text { GF Diversity } & .590 & .707 & .211\end{array}$

YEARS * INTENSITY

$\begin{array}{llll}\text { Richness } & 2.067 & .038 & .857 \\ \text { Diversity } & 2.598 & .009 & .937 \\ \text { Evenness } & 1.378 & .207 & .421 \\ \text { GF Diversity } & 1.949 & .051 & .756\end{array}$

YEARS * GRAZING SYSTEM * INTENSITY

\begin{tabular}{lrll} 
Richness & 1.351 & .220 & .641 \\
Diversity & .523 & .869 & .250 \\
Evenness & .700 & .722 & .360 \\
GF Diversity & .853 & .580 & .489 \\
\hline
\end{tabular}

grazed pastures, and although the ungrazed pasture showed significantly lower species richness overall compared to grazed sites, it showed similar interannual fluctuations in mean plant species richness varying from 25 to 33 species/transect during the 6 year study period.

We found no significant effect of stocking density on evenness of species relative abundances (Pielou's index; Table 1). However, plant species diversity (Shannon index; $\left.H^{\prime}\right)$ was significantly higher in the high stocking density compared to the low stocking density treatments (Tukey's; P = 0.028 ), although differences between moderate and low stocking densities and moderate and high stocking densities were not significant (Fig. 2). These patterns of increasing species diversity were established within the first year of grazing treatments and remained consistent throughout the remaining 5 years of study (Fig. 2). Growth form diversity also was significantly higher in the high stocking density treatments relative to the low density treatments $(P=0.018)$ with the low vs. moder- 


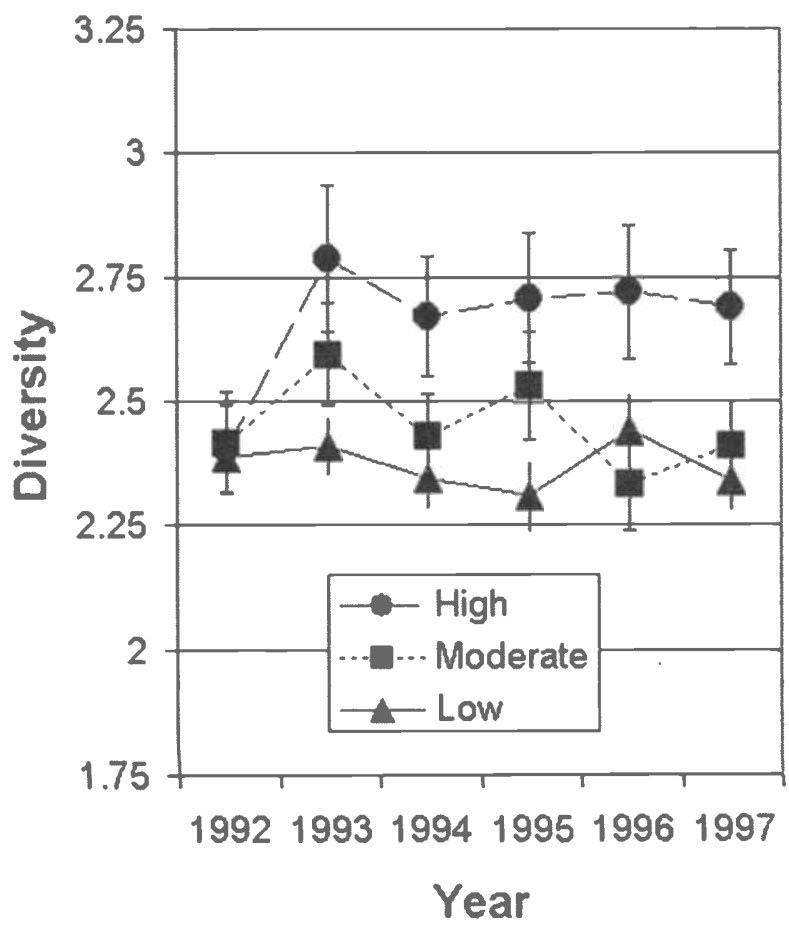

Fig. 2. Annual means \pm 1 SE (1992-1997) of plant species diversity $\left(H^{\prime}\right)$ at 3 stocking densities in Kansas tallgrass prairie. $H^{\prime}=$ Shannon's species diversity index $\left(H^{\prime}=-\sum p_{i} l n p_{i}\right.$, where $p_{i}=$ the frequency of species $i$ ). Low $=3.8$ hectares/cow-calf pair, moderate $=\mathbf{2 . 8} \mathrm{ha} /$ cow-calf pair, and high $=\mathbf{1 . 8} \mathrm{ha} /$ cow-calf pair stocking densities.

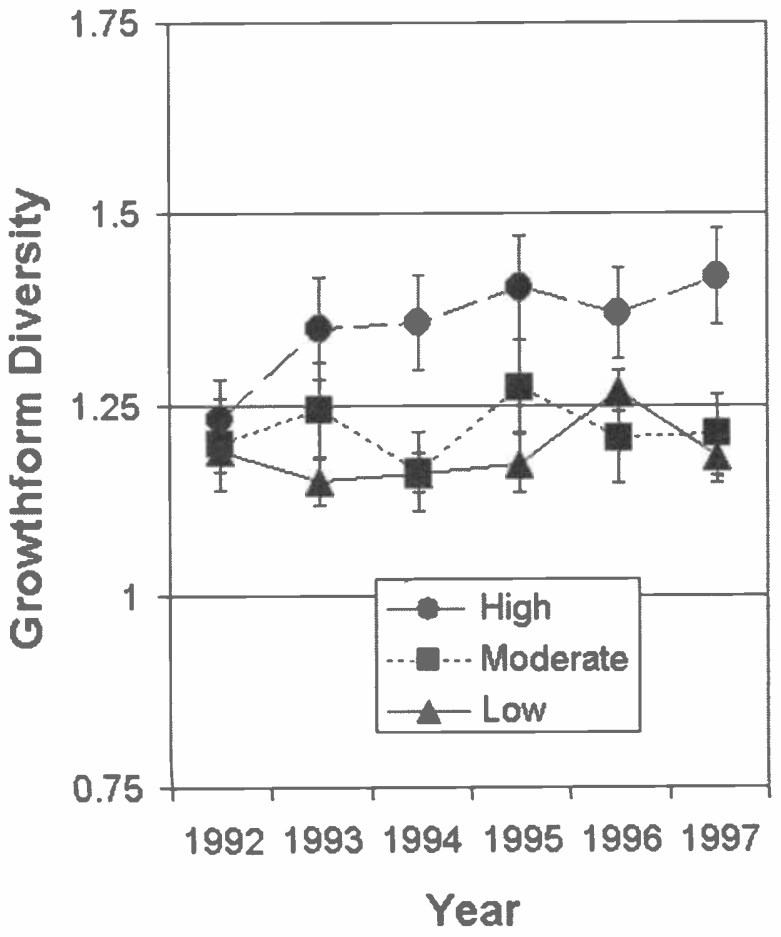

Fig. 3. Annual means \pm 1 SE (1992-1997) of plant growth form diversity $(\mathrm{GF} H \notin)$ at varying stocking densities in Kansas tallgrass prairie. GF $H^{\prime}=$ Shannon's diversity index $\left(H^{\prime}=-\sum p_{i} \ln p_{i}\right.$, where $\mathrm{p}_{\mathbf{i}}=$ the frequency of growth form $\mathrm{i}$ ). STOCKING DENSITIES: Low $=3.8$ hectares/cow-calf pair, moderate $(2.8 \mathrm{ha} /$ cow-calf pair $)$, and high (1.8 ha/cow-calf pair). ate and high vs. moderate stocking densities not significantly different (Fig. 3). A separate analysis of species richness and diversity, removing all non-native or alien species revealed similar trends.

Abundances of different plant growth forms varied in response to grazing intensity treatments (Figs. 4-6). Significant effects of stocking density on the year to year frequency of $\mathrm{C}_{4}$ tall grasses (e.g., big bluestem, Indian grass, and switchgrass), $\mathrm{C}_{4}$ mid-grasses (e.g., little bluestem, sideoats grama [Bouteloua curtipendula (Michx.) Torr.]) and annual forbs emerged within the first 2 to 3 years of the grazing treatments. By contrast, cattle stocking density had no significant effect on the frequencies of $\mathrm{C}_{4}$ shortgrass species (e.g. hairy grama [Bouteloua hirsuta Lag.], blue grama [B. gracilis (H.B.K.) Lag. ex Griffiths] buffalograss [Buchloe dactyloides (Nutt.) Engelm.]), $\mathrm{C}_{4}$ annual grasses, $\mathrm{C}_{3}$ perennial and annual grasses, perennial forbs, or woody species.

The $\mathrm{C}_{4}$ tall grasses were the most abundant component of the plant community with frequency generally greater than $50 \%$ in all sites. Significant differences in frequency of $\mathrm{C}_{4}$ perennial tall grasses were found between low and moderate stocking densities and between low and high stocking densities, however no significant differences between high and moderate stocking densities were found (Fig. 4). After year 3 of the study, the frequency of $\mathrm{C}_{4}$ tall grasses in the low stocking density had increased to $>60 \%$ and remained significantly higher than either the high or moderate stocking density treatments the remaining 3 years of the study (Fig. 4).

Frequency of $\mathrm{C}_{4}$ perennial mid-grasses showed trends exactly opposite of $\mathrm{C}_{4}$ perennial tall grasses (Fig. 5). After the 3rd year of the study, a consistent pattern emerged of lowest frequency of midgrasses in the low stocking density treatment compared to the moderate and high stocking densities. The frequency of annual forbs (Fig. 6) differed significantly among years. In 1994, 1995, and 1996 there was a consistent trend of increased frequency of annual forbs under moderate stocking densities relative to other grazed treatments. However, the repeated measures MANOVA indicated there was no overall significant effect of stocking density on this group of plants. Patterns of annual forb frequency across years clearly indicated greater interannual variability among the different stocking densities than evident in the perennial species (Fig. 6).

\section{Discussion}

Two important components of a grazing management strategy influencing plant communities include the animal stocking density and the grazing system. The stocking density (number of animals per unit area) influences the overall intensity of herbivory and physical impacts, and the grazing system determines the spatial and temporal patterns of grazing and their effects across the landscape. In this study, stocking density had significant effects on tallgrass prairie plant species composition and diversity, but there was no significant effect of grazing system (e.g. season-long versus late-season rest rotation) nor significant interactions between grazing systems and stocking density. These results strongly indicate that animal density is a key management variable influencing species diversity and composition in tallgrass prairie, whereas the grazing system has a much smaller, if any effect on plant community structure. This is somewhat surprising, given that plant species with varying growth and reproductive phenology may be expected to show differential responses to variation in the temporal pattern of herbivory across the season. It is 


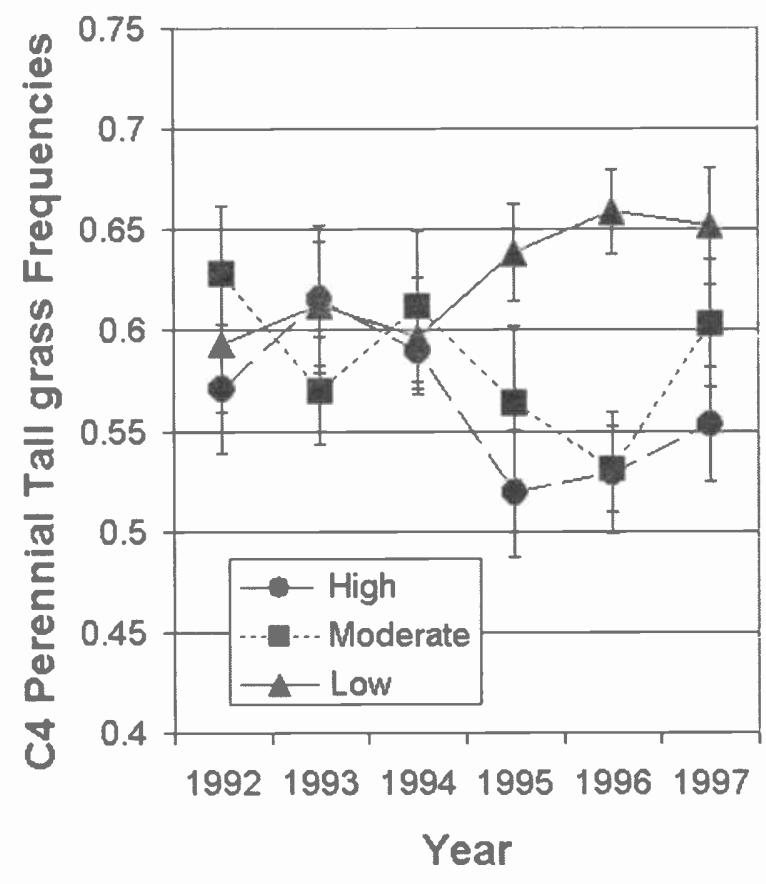

Fig. 4. Annual means $\pm 1 \mathrm{SE}(1992-1997)$ of $\mathrm{C}_{4}$ perennial tallgrass growth form frequencies per treatment each year of study at varying stocking densities in Kansas tallgrass prairie. STOCKING DENSITIES: Low $=3.8$ hectares/cow-calf pair, moderate $(2.8 \mathrm{ha} /$ cow-calf pair), and high (1.8 ha/cow-calf pair).

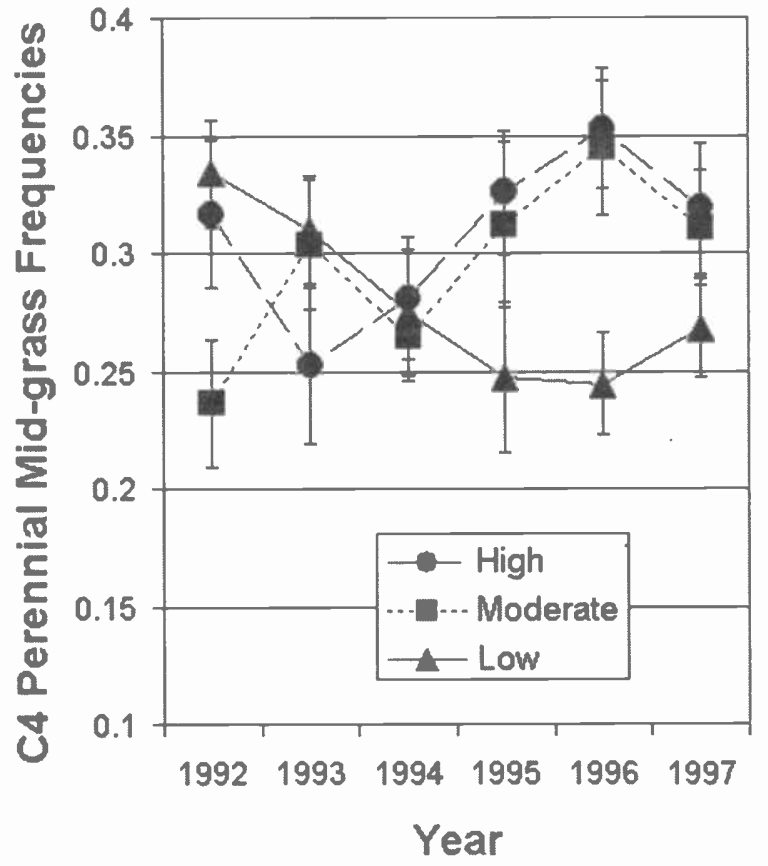

Fig. 5. Annual means \pm 1 SE (1992-1997) of C4 midgrass frequency per treatment each year of study at varying stocking densities in Kansas tallgrass prairie. STOCKING DENSITIES: Low $=3.8$ hectares/cow-calf pair, moderate ( $2.8 \mathrm{ha} / \mathrm{cow}$-calf pair), and high (1.8 ha/cow-calf pair). possible that, in this study, individual species did indeed vary in their responses to the different grazing systems, but that a similar number of positive and negative responses among species resulted in no net effect on overall plant species richness or diversity. Overall, the results here support the suggestions of other workers that vegetation responses to grazing systems may be strongly dependent on, or over-ridden by effects of stocking density, and that animal density is generally the most important grazing management variable affecting plant community structure in rangeland ecosystems (Gammon and Roberts 1978, Gillen at al. 1991, Hart et al. 1988, Heitschmidt et al. 1987).

Several clear trends among different plant groups in response to grazing intensity were evident. The dominant native $\mathrm{C}_{4}$ perennial tall grasses decreased in abundance with grazing, an effect that became more pronounced with increasing stocking densities. Previous work has shown that grazing and fire have opposite effects on the competitive dominance of the warmseason perennial grasses in tallgrass prairie (Knapp et al. 1998, Hartnett et al. 1996). In the present study, the pronounced decrease in the abundance of $\mathrm{C}_{4}$ tall grasses at the moderate and high stocking densities was likely due to a com- bination of both their high rates of consumption as preferred forage grasses, and the less complete and more heterogeneous burns that occurred in these more heavily grazed pastures. Although these dominant grasses responded to grazing, they changed in abundance less than other plant groups, and they showed relatively little inter-annual fluctuations in abundance, generally varying by not more than $10 \%$ among years within treatments. This is indicative of the general stability and resiliency of the dominant perennial grasses, relative to other components of the tallgrass prairie plant community, under varying grazing management (Launchbaugh and Owensby 1978).

By contrast, both $\mathrm{C}_{4}$ mid-grasses and short grasses were generally more abundant in moderately- to intensively-grazed prairie relative to ungrazed or lightlygrazed sites, whereas $C_{3}$ perennial grasses changed little in response to grazing. The $\mathrm{C}_{3}$ grasses decreased in abundance with frequent spring burning in tallgrass prairie (Hartnett and Fay 1998), and their increasing frequency with increasing stocking density observed here may be due to a reduced influence of fire, as heavy grazing resulted in lower mass and greater patchiness of fuel, and thus patchy and lowerintensity fires.
In tallgrass prairie, although grasses comprise the largest fraction of plant biomass and productivity and are the most important forage component for large grazers, forb species outnumber grasses by an order of magnitude. In addition, the distribution and abundance of forbs are largely responsible for the pattern of small- and mid-scale vegetation diversity (heterogeneity), and forbs are more diagnostic of environmental conditions (Biondini et al. 1989). The overall abundance of perennial forbs exhibited no significant trends across treatments, suggesting that this group of species also shows relatively high stability across stocking density and grazing system combinations. However, this result may reflect the net effect of 2 opposite responses among forb species. Several tallgrass prairie forbs are not directly consumed by ungulates and show competitive release (increase in abundance) in response to grazing of their neighboring highly competitive perennial grasses (Fahnestock and Knapp 1993, Damhoureyeh and Hartnett 1997). Other forbs are grazed heavily and their frequency decreases. The net effect of these 2 opposite species responses may account for the lack of overall change to total perennial forb abundance.

Despite their high fluctuations in abun- 


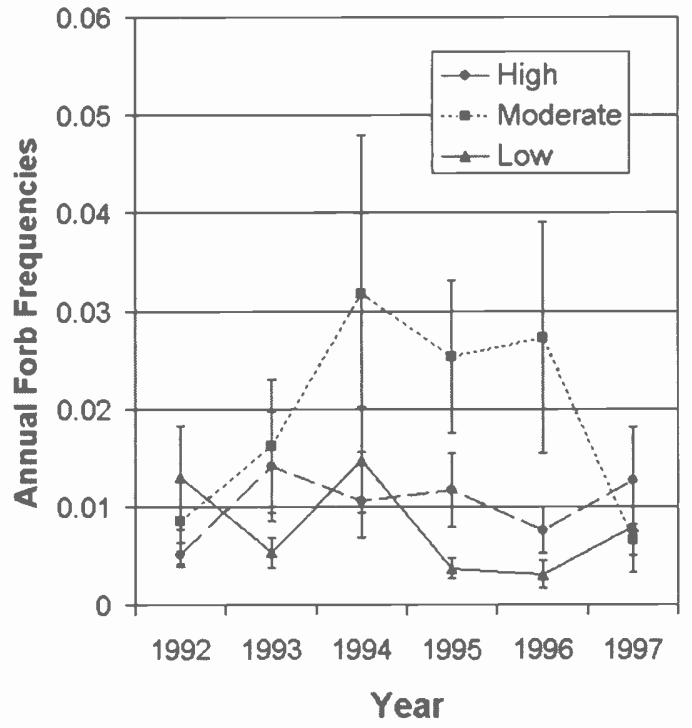

Fig. 6. Annual means \pm 1 SE (1992-1997) of annual forb frequency per treatment each year of study at varying grazing system/stocking density combinations in Kansas tallgrass prairie. STOCKING DENSITIES: Low $=3.8$ hectares/cow-calf pair, moderate $(2.8$ ha/cow-calf pair), and high (1.8 ha/cow-calf pair).

dance among years, annual forbs were more abundant overall in grazed treatments than in ungrazed prairie. In the 3 out of 6 years in which grazing had a significant effect, annuals consistently showed greatest abundance under the intermediate cattle stocking density. This pattern was unexpected and its cause is unclear. Perhaps, as predicted by the intermediate disturbance hypothesis (Connell 1978) the abundance of many of these colonizers is limited by strong competitive suppression by perennial grasses under low grazing intensities, and limited by restricted opportunities for successful establishment and persistence under intense grazing. The highly variable patterns of abundance of annual forbs among years and treatments likely is strongly related to their complete dependence upon successful reproduction from seed for local population maintenance. A number of factors, including grazer effects on variation in microsite availability, spatial patterns of fire, and competitive effects of dominant grasses, and interannual variability in precipitation all contribute to the unpredictability of successful establishment from seed in annuals and their local instability in abundances. Although in general, annual and perennial forbs comprise a much smaller fraction of the total biomass and productivity of tallgrass prairie relative to the dominant perennial grasses, they represent a large number of subdominant and transient species that may nonetheless have important influ- ences on ecosystem processes (Grime 1998), contribute to vegetation complexity and microhabitat diversity (Collins and Steinauer 1998), and serve as the resource base for other vertebrate and invertebrate consumers (Cook 1983, Kaufman et al. 1998).

Grazing by cattle increased diversity in these tallgrass prairie plant communities. Cattle stocking density had significant effects on the composition, species richness, species diversity, and growth form diversity of plants, with the highest stocking density resulting in highest diversity. body of evidence indicating that grazing by large ungulate herbivores (whether native grazers such as bison or domestic cattle) generally increases floristic diversity in tallgrass prairie, and that grazing and fire interact to modulate diversity in these systems (Hartnett et al. 1996, Collins et al. 1998, Knapp et al. 1998). Our finding of significant effects of grazing on plant species diversity with or without inclusion of non-native species in the analyses demonstrates that enhancement of plant species richness under livestock grazing is not attributable to increased disturbance and increased frequency of weedy exotic species. In addition, large fluctuations in the abundance of different plant species among years within treatments (e.g. high variability in annual forbs and in plant species richness in ungrazed prairie) indicates significant inter-annual variability in plant community structure, independent of grazing effects. These results emphasize These results further support a growing that the effects of grazing in tallgrass prairie occur in the context of a temporally dynamic non-equilibrium system, influenced strongly by annual climatic variability and interactions with other natural disturbances and processes operating at different scales (Knapp et al. 1998).

Theoretical models such as the intermediate disturbance hypothesis or the model of Milchunas et al. (1988) predict highest species diversity at intermediate levels of grazing in tallgrass prairie and other subhumid grasslands. However, our results indicate a monotonic increase in diversity with greatest diversity at our highest grazing intensity. This suggests that either cattle stocking densities greater than 1.8 ha per cow-calf pair, or the maintenance of high stocking densities over longer periods, are required to cause a decline in plant diversity in tallgrass prairie. Also, precipitation was slightly above the longterm average during the 6 years of this study, and diversity may not be maintained at high stocking densities during periods of below-average precipitation. Moreover, alteration of the soil environment and ecosystem processes that may occur under higher grazing intensities (Archer and Smeins 1991, West 1993, Chapin et al. 1998) may, over the longer term, drive future changes in plant species composition and diversity in response to grazing management.

The importance of understanding the long-term ecological consequences of different grazing management practices is essential to provide a sound basis for selecting among range management alternatives, particularly in cases where their short-term effects on forage or animal production are similar, but their long-term ecological effects are significantly different. Furthermore, effects of varying management such as stocking densities and grazing systems on plant species diversity and the relative abundances of different growth forms or functional groups may have important consequences for grassland community stability and ecosystem functioning, which in turn can influence the long-term sustainability of plant and animal productivity.

\section{Literature Cited}

Anderson, K.L. and C.L. Fly. 1955. Vegetation-soil relationships in Flint Hills bluestem pastures. J. Range Manage. 8:163-169.

Anderson, K.L., E.F. Smith, and C.E. Owensby. 1970. Burning bluestem range. J. Range Manage. 23:81-92. 
Archer, S.A. and F.M. Smeins. 1991. Ecosystem-level processes. Pages 109-139. In: R.K. Heitschmidt and J.W. Stuth (eds.) Grazing Management: An Ecological Perspective. Timber Press, Portland, Ore.

Biondini, M.E., B.D. Patton, and P.E. Nyren. 1998. Grazing intensity and ecosystem processes in a northern mixed-grass prairie, USA. Eco. Appl. 8:469-479.

Biondini, M.E., A.A. Steuter, and C.E. Grygiel. 1989. Seasonal fire effects on the diversity patterns, spatial distribution and community structure of forbs in the northern mixed prairie, USA. Vegetatio 85:21-31.

Briggs, J. and A.K. Knapp. 1995. Interannual variability in primary production in tallgrass prairie: climate, soil moisture, topographic position, and fire as determinants of aboveground biomass. Am. J. Bot. 82:1024-1030.

Chapin, F.S., O.E. Sala, I.C. Burke, J.P. Grime, D.U. Hooper, W.K. Lauenroth, A. Lombard, H.A. Mooney, A.R. Mosier, S. Naeem, S.W. Pacala, J. Roy, W.L. Steffen, and D. Tilman. 1998. Ecosystem consequences of changing biodiversity. Bioscience 48:45-52.

Collins, S.L. and E.M. Steinauer. 1998. Disturbance, diversity, and species interactions in tallgrass prairie. Pages $140-156 . I n$ : A.K. Knapp, et al., (Eds). Grassland Dynamics: Long-term Ecological Research in Tallgrass Prairie. Oxford Univ. Press.

Collins, S.L., A.K. Knapp, J.M. Briggs, J.M. Blair, and E.M. Steinauer. 1998. Modulation of diversity by grazing and mowing in native tallgrass prairie. Sci. 280:745-747.

Connell, J.H. 1978. Diversity in tropical rain forests and coral reefs. Sci. 199:1302-1310.

Cook, C.W. 1983. "Forbs" need proper ecological recognition. Rangelands 5:217-220.

Coughenour, M.B. 1991. Spatial components of plant-herbivore interactions in pastoral, ranching, and native ungulate ecosystems. J. Range Manage. 44:530-542.

Damhoureyeh, S.A. and D.C. Hartnett. 1997. Effects of bison and cattle on growth, reproduction, and abundances of five tallgrass prairie forbs. Amer. J. Bot. 84:1719-1728.

Fahnestock, J.T. and A. K. Knapp. 1993. Water relations and growth of tallgrass prairie forbs in response to selective herbivory by bison. Intl. J. Plant Sci. 154:432-440.

Gammon, D.M. 1978. A review of experiments comparing systems of grazing management on natural pastures. Proc. Grassl. Soc. South Africa 13:75-82.

Gammon, D.M. and R.B. Roberts. 1978. Patterns of defoliation during continuous and rotational grazing of the Matapos Sandveld in Rhodesia. 1. Selectivity of grazing. Rhodesian J. Agr. Res. 16:117-131.

Gillen, R.L., F.T. McCollum, K.W. Tate, and M.E. Hodges. 1998. Tallgrass prairie response to grazing system and stocking rate. J. Range Manage. 51:139-146.

Gillen, R.L., F.T. McCollum, M.E. Hodges, J.E. Brummer, and K.W. Tate. 1991. Plant community responses to short duration graz- ing in tallgrass prairie. J. Range Manage. 44:124-128.

Grime, J.P. 1998. Benefits of plant diversity to ecosystems: immediate, filter, and founder effects. J. Ecol. 86:902-910.

Hart, R.H. 1978. Stocking rate theory and its application to grazing on rangelands. Pages 547-550 In: D.N. Hyder (ed.) Proc. First Intl. Rangelands Cong. Soc. Range Manage., Denver, Colo.

Hart, R.H., M.J. Samuel, P.S. Test, and M.A. Smith. 1988. Cattle, vegetation, and economic responses to grazing systems and grazing pressure. J. Range Manage. 41:282-286.

Hartnett, D.C. and P.A. Fay. 1998. Plant populations: patterns and processes. Pages 81-100. In: A. K. Knapp, J. M. Briggs, D.C. Hartnett, and S.L. Collins (eds.) Grassland Dynamics: Long-term Ecological Research in Tallgrass Prairie. Oxford University Press, New York, N.Y.

Hartnett, D.C., K.R. Hickman, and L.E. Fischer-Walter. 1996. Effects of bison grazing, fire, and topography on floristic diversity in tallgrass prairie. J. Range Manage. 49:413-420.

Heitschmidt, R.K. and C.A. Taylor, Jr. 1993. Livestock Production. Pages 161-177. In: R.K. Heitschmidt and J.W. Stuth (eds.) Grazing Management: An Ecological Perspective. Timber Press, Portland, Ore.

Heitschmidt, R.K., S.L. Dowhower, and J.W. Walker. 1987. Some effects of rotational grazing treatment on quantity and quality of available forage and amount of ground litter. J. Range Manage. 40:318-321.

Herbel, C.H. and K.L. Anderson. 1959. Response of True Prairie vegetation on major Flint Hills range sites to grazing treatment. Ecol. Mono. 29:171-186.

Kaufman, D.W., G.A. Kaufman, P.A. Fay, J.L. Zimmerman, and E.W. Evans. 1998. Diversity of terrestrial macrofauna. Pages 113-139. In: A. K. Knapp, J. M. Briggs, D.C. Hartnett, and S.L. Collins (eds.) Grassland Dynamics: Long-term Ecological Research in Tallgrass Prairie. Oxford Univ. Press.

Knapp, A.K., J.M. Briggs, D.C. Hartnett, and S.L. Collins. 1998. Grassland Dynamics: Long-term Ecological Research in Tallgrass Prairie. Oxford Univ. Press, New York, N.Y.

Launchbaugh, J.L. and C.E. Owensby. 1978. Kansas rangelands: their management based on a half century of research. KS Agr. Expt. Sta. Bull. 622. Manhattan, Kans.

Magurran, A.E. 1988. Ecological Diversity and Its Measurement. Princeton Univ. Press, Princeton, N.J.

McKendrick, J.D., C.E. Owensby, and R.M. Hyde. 1975. Big bluestem and Indiangrass vegetative reproduction and annual reserve carbohydrate and nitrogen cycles. AgroEcosystems 2:75-93.

Milchunas, D.G., O.E. Sala, and W.K. Lauenroth. 1988. A generalized model of the effects of grazing by large herbivores on grassland community structure. Am. Nat. 132:87-106.

Owensby, C.E. 1973. Modified step-point system for botanical composition and basal cover estimates. J. Range Manage. 26:302-303.

Owensby, C.E., R.C. Cochran, and L.M. Auen. 1995. Effects of sorghum grain supplementation on livestock performance, botanical composition, and herbage yield of intensive-early stocked bluestem range. J. Range Manage. 48:246-250.

Owensby, C.E., E.F. Smith, and K.L. Anderson. 1973. Deferred-rotation grazing with steers in the Kansas Flint Hills. J. Range Manage. 26:393-395.

Owensby, C.E., E.F. Smith, and J.R. Rains. 1977. Carbohydrate and nitrogen reserve cycles for continuous, season-long and intensive-early stocked Flint Hills bluestem range. J. Range Manage. 30:258-260.

Samson, F.B. and F.L. Knopf. 1996. Prairie Conservation: Preserving North America's Most Endangered Ecosystem. Island Press, Washington, D.C.

Schlapfer, F. and B. Schmid. 1999. Ecosystem effects of biodiversity: a classification of hypotheses and exploration of empirical results. Eco. Appl. 9:893-

Smith, J.G. 1895. Forage conditions of the prairie region. Pages 309-324. In: USDA Yearbook of Agriculture - 1895.

Smith, E.F. and C.E. Owensby. 1978. Intensive-early stocking and season-long stocking of Kansas Flint Hills range. J. Range Manage. 31:14-17.

Stohlgren, T.J., L.D. Schell, and B.V. Heuvel. 1999. How grazing and soil quality affect native and exotic plant diversity in Rocky Mountain grasslands. Eco. Appl. 9:45-64.

Tilman, D. 1996. Biodiversity: population versus ecosystem stability. Ecol. 77:350-363.

Towne, G. and C.E. Owensby. 1984. Longterm effects of annual burning at different rates on ungrazed Kansas tallgrass prairie. J. Range Manage. 37:392-397.

West, N.E. 1993. Biodiversity of rangelands. J. Range Manage. 46:2-13. 